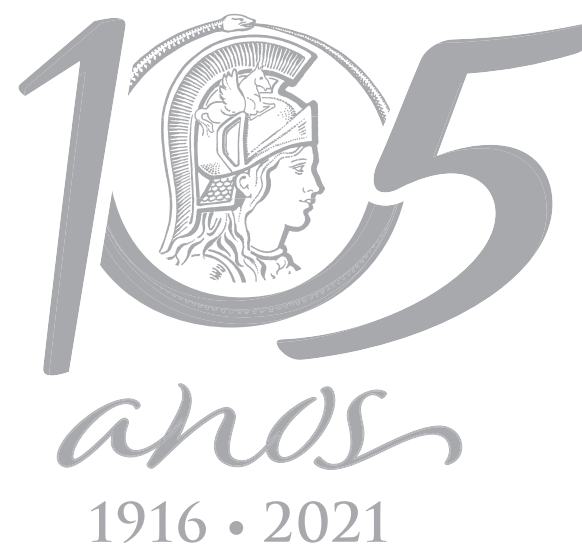

\title{
Curcuma longa hydrolate improves Nile tilapia survival in a recirculation rearing system, maintaining the animal homeostasis and modulating the gut microbial community
}

\author{
MARINA O. PEREIRA, JULIA D. HESS, JULIO CESAR B. RODHERMEL, DANIEL R. \\ FARIAS, DELANO D. SCHLEDER, LUCIANO ALVES, FABIANO C. BERTOLDI, AMANDA \\ CHABAN, JAQUELINE I.A. DE ANDRADE \& ADOLFO JATOBÁ
}

\begin{abstract}
This study aimed to evaluate the effects of the dietary supplementation Curcuma longa hydrolate on Nile tilapia (Oreochromis niloticus) reared in a recirculation system. Hemato-immunological parameters, growth performance, nitrogen and phosphorus retention, as well as body composition and its interaction with the intestinal microbiota, were studied. Nile tilapia fingerlings (120) were distributed randomly in 8 polyethylene tanks $(40 \mathrm{~L})$. The experimental units were divided into two treatments, in quadruplicate: commercial diet supplemented with $2.5 \%$ of $C$. longa hydrolate and commercial diet without supplementation (control). After 45 days, the treatment supplemented hydrolate showed higher survival than the control group, 95.25\% and $82.22 \%$, receptively. In the blood profile, fish supplemented with hydrolate had a higher count of total leukocytes and neutrophils, as well as mean corpuscular hemoglobin and mean corpuscular hemoglobin concentration, than control group. The hydrolate group showed a substantial increase in the relative abundance of Cetobacterium and Romboutsia, as well as lower diversity in gut microbiota. The dietary addition of C. longa hydrolate for Nile tilapia seems to have a beneficial effect on gut microbiota, in addition to a likely positive effect on the physiological performance of Nile tilapia by maintaining intestinal homeostasis and promoting survival in reared conditions.
\end{abstract}

Key words: aquaculture, curcumin, herbal medicines immunomodulatory, Oreochromis niloticus.

\section{INTRODUCTION}

Aquaculture has become the main activity for the provision of fishery, increasing in production by $60 \%$ between 2007 and 2017 and ensuring an adequate supply of aquatic animal protein to the growing world population (Ocde/Fao). The worldwide production rose from 50 million / t / year to 80 million / $t$, while Brazilian production reached 722,560 tons in 2018 (Anuário Peixe-BR 2021).
Fish farming in Brazil produced 802 thousand tons in 2020, Nile tilapia (Oreochromis niloticus) is the most produced species in Brazil, representing more than $55.0 \%$ of national production, thereby consolidating the country as the fourth largest tilapia producer in the world (Anuário Peixe-BR 2021). This growth in production could be associated with the fast growth Nile tilapia, its ability to adapt to artificial food and intensive production systems, in addition to its acceptance by the consumer market based on being considered a source 
of healthy animal protein. (Lunkes et al. 2018, Vicente et al. 2014).

However, in recent years, the intensification of aquaculture systems associated with high stocking densities have contributed to increase outbreak disease and its transmission. As a treatment, chemotherapeutic substances are frequently used, but the indiscriminate use of these drugs, coupled with poor administration and failed management techniques, has resulted in the selection of microorganisms resistant to a wide variety of active principles (Cabello et al. 2013). This situation calls for a review and improvement of management techniques, especially preventive ones. Several simple options are possible, including liming, monitoring of water quality parameters, asepsis of the materials used in the tanks/ponds, as well as the application of vaccines, probiotics and food additives (Jatobá et al. 2016).

World associations, such as the World Organization for Animal Health and Codex Alimentarius, have called on all sectors of animal production to engage in a global campaign to reduce antimicrobials based on a unique concept of health which links humans, animals and the environment (Torres 2019). Concomitantly, demand has grown for certified products, ensuring that a given product has been reared within the standards of environmental and social responsibility, food safety, animal welfare and traceability of the entire production cycle (Bergleiter \& Simon 2015).

Thus, it is important to search for alternative products, such as herbal medicines, that are of natural origin. They can be presented in the form of extracts, essential oils or hydrolate, all of which have some pharmacological properties like antimicrobial (De Souza et al. 2020), antiparasitic (Andrade et al. 2018) and immunomodulatory (Pereora et al. 2020) activity in fish.
Turmeric (Curcuma longa), one of the precious spices of world cuisine, is also used to treat many diseases because it has antioxidant, immunomodulatory, anti-inflammatory and tumor cell suppression effects (Kocaadam \& Şanlier 2017). As one of its main components, this plant has curcumin which has antimicrobial activity against pathological bacteria, as reported in many studies, including those focused on aquaculture (Singh et al. 2017). For instance, it has promoted higher tolerance to stress during the transport of yellow-tailed lambari (Ferreira et al. 2017) and better zootechnical and immune performance of Nile tilapia (Abdel-Tawwab \& Abbass 2017).

In particular, hydrolate is the aqueous fraction that contains the emulsified essential oil, and it is usually discarded, but many studies have proven the efficiency of this by-product. Catão et al. (2018), for example, observed the fungicidal activity of Lippia menosides hydrolate on the storage of castor seeds (Ricinus communis). In addition, Mello et al. (2015) verified the effectiveness of garden rosemary hydrolate (Rosmarinus officinalis) to control ticks, while the essential oil of this perennial evergreen shrub with blue flowers has shown less acaricidal activity, validating the effectiveness of its hydrolate by-product, which has, so far, been neglected.

The intestine plays an important role for farm animals, including fish, as it acts directly on the digestion and absorption of nutrients, but it also has a relevant function in the immune system (Salinas \& Parra 2015). Many infectious diseases are caused by pathogenic bacteria that break down intestinal homeostasis, affecting commensal bacteria in that area and affecting epithelial integrity. In their study with Nile tilapia that fed a diet supplemented with turmeric, Yusuf et al. (2017) evidenced an increase in intestinal villi, a decrease in the total 
bacteria count and an increase in Lactobacillus spp. compared to the control group, observing a better zootechnical performance in the group supplemented with $2 \mathrm{~g} / \mathrm{Kg}$ of curcuma longa powder. Furthermore, C. longa hydrolate changed the hematological and immunological parameters of Nile tilapia (O. niloticus) fingerlings, keeping fish healthy (Pereira et al. 2020). Therefore, this study aimed to evaluate the effects of the dietary supplementation Curcuma longa hydrolate on Nile tilapia (Oreochromis niloticus) reared in a recirculation system. Hemato-immunological parameters, growth performance, nitrogen and phosphorus retention, as well as body composition and its interaction with the intestinal microbiota, were studied.

\section{MATERIALS AND METHODS}

This study was carried out in the Laboratorio de Aquicultura (Laq) do Instituto Federal Catarinense (IFC), Campus Araquari, and it was approved by the National Council for the Control of Animal Experimentation (CONCEA) under protocol number 157/2016.

\section{Plant material}

The botanical species used in this work was grown in the Medical Plants Unit at the IFC, located at $26^{\circ} 23^{\prime} 33.6691^{\prime \prime} \mathrm{S}$ and $48^{\circ} 44^{\prime} 18.3336^{\prime \prime}$ W, at $10.6 \mathrm{~m}$ above sea level, City of Araquari, Santa Catarina State, southern Brazil. Plants were cultivated in an agroecological system without the application of agrochemical products. Tumeric (Curcuma longa) was collected from approximately 50 individuals. A voucher specimen of the botanical material was deposited at the Botanical Museum Herbarium located in the Botanic Garden of Curitiba, PR, with the number 358970 .

\section{Obtaining the hydrolate}

C. longa hydrolate, a by-product of EO distillation, was achieved by hydrodistillation (Venskutonis et al. 1997) using the Clevenger apparatus adapted to a 2000 mL flask, in which the mint leaves were placed together with $1000 \mathrm{~mL}$ of distilled water according to Coradi et al. (2018). Fresh Curcuma longa (150g) was used for each distillation. The extraction time was $90 \mathrm{~min}$, starting from the time of boiling. After the hydrolate (mixture of oil and water) was obtained, separation of the essential oil was initiated using the organic solvent pentane (3 x50 mL) in a separating funnel. After a few minutes of resting, the solution was filtered and concentrated on a rotary evaporator at $40^{\circ} \mathrm{C}$ until the solvent volume was significantly reduced.

The hydrolate obtained from the hydrodistillation of $\mathrm{C}$. longa was treated with chromatographic grade hexane, followed by performing a liquid-liquid extraction with approximately $2 \mathrm{ml}$ of hexane for $100 \mathrm{~mL}$ of hydrolate in a separating funnel. A $500 \mu \mathrm{L}$ fraction of the organic phase was collected to perform a chemical analysis of the volatile components of the hydrolate of $C$. longa by gas chromatography with a mass spectrometry detector (GCMS, Shimadzu, model GCMS - QP2010). A ZB-5MS capillary column $(30 \mathrm{~m} \times 0.25 \mathrm{~mm} \times 0.25 \mu \mathrm{m}$ film) was used. Injector temperature was $250^{\circ}$ $\mathrm{C}$, and helium carrier gas flow was $1.0 \mathrm{~mL}$. $\mathrm{min}^{-1}$. The chromatograph oven was optimized with an initial temperature of $60{ }^{\circ} \mathrm{C}$ for 4 minutes until reaching $210{ }^{\circ} \mathrm{C}$ and then remaining for 6 minutes, totaling 35 minutes in the complete chromatographic run. A fraction extracted from hydrolate was diluted 2 times in chromatographic grade hexane for subsequent injection of $1 \mu \mathrm{L}$ in GCMS. The quantification of each component was determined by normalizing the areas (\%) of the peaks in the total ion chromatogram (TIC), 
with the total area being the sum of all areas of the eluted peaks (100\%).

Retention rates were calculated according to Dool \& Kratz (1963) from n-alkane standards (C7C30) under the same chromatographic conditions as samples of essential oils. The identification by GCMS was based on the comparison of mass spectra with NIST-05 data libraries and also by comparing the retention rates calculated with those found in the literature (databases WebNIST, GMD).

\section{Experimental design and management}

The research was performed using 120 Nile tilapia fingerlings (Oreochromis niloticus) with a mean weight of $0.85 \pm 0.08 \mathrm{~g}$. Fingerlings were distributed randomly in 8 polyethylene tanks (40 L) equipped with constant water renewal in an aquaculture recirculation system. The experimental units were divided into two treatments, in quadruplicate: commercial diet supplemented with $2.5 \%$ of C. longa hydrolate, according to the protocols established by Pereira et al. (2020), and commercial diet without supplementation (control).

Fish were fed a commercial diet three times a day $\left(08: 00,12: 00\right.$ and 16:00) $\left(G \cup A B I{ }^{\circledR}, 1.0 \mathrm{~mm}\right.$, 45\% crude protein and $8.0 \%$ ethereal extract, manufacturer's warranty levels), with $3 \%$ of their biomass, and biometrics was performed weekly for food management, while $\mathrm{pH}$ and ammonia were measured weekly. The water quality parameters were as follows: dissolved oxygen above $4.5 \mathrm{mg} \mathrm{L}^{-1}$ and temperature $22.21 \pm 1.71^{\circ} \mathrm{C}$ (YSI55 oximeter); alkalinity between 88.3 - 142.1 $\mathrm{mg} \mathrm{CaCo}$ total $\mathrm{L}^{-1}$; ammonia total $0.22 \pm 0.09 \mathrm{mg}$ $\mathrm{L}^{-1}$; nitrite $0.05 \pm 0.06 \mathrm{mg} \mathrm{L}^{-1}$ and $\mathrm{pH} 7.36 \pm 0.09$, all measured twice a week according to APHA (2005).

\section{Data collection and growth performance}

After 45 days of rearing and a $24 \mathrm{~h}$ period of starvation, 10 fish per experimental unit were anesthetized with Eugenol (50 mg. $\left.\mathrm{L}^{-1}\right)$ and euthanized by cerebral concussion. Five were used for hematological and immunological assays, and the other five for body analysis. The first three animals per experimental unit used for blood sampling for hematological and immunological assays were also used to collect gut content for metagenomic analysis. The gut content from nine fish per treatment (three per experimental unit) was gathered to make a single sample pool (200 mg) prior to total DNA extraction and further analyses. In addition, a final biometry was performed, and hepatosomatic index (liver weight / body weight * 100), specific growth rate (final weight - initial weight / initial weight), protein efficiency rate (weight gain / total consumption of protein), yield and survival were determined according Jatobá et al. (2014).

\section{Hematological and immunological analysis}

For hematological analysis, approximately 0.5 $\mathrm{mL}$ of blood was drawn from the caudal vein of each fish for the preparation of blood smears, in duplicate, and the following hematological analyses were performed: determination of hematocrit by the standard microhematocrit method; glucose (G-TECH free ${ }^{\circledR}$, AccumedGlicomed, Brazil); total hemocyte count by Neubauer hemocytometer and hemoglobin concentration. Hematimetric absolute rates of mean corpuscular volume (MCV), mean corpuscular hemoglobin (MCH) and mean corpuscular hemoglobin concentration ( $\mathrm{MCHC}$ ) were also obtained. Blood smear slides were stained with May-Grünwald-Giemsa (MGG) stain (Ranzani-Paiva et al. 2013) for total and differential leukocyte count (Jatobá et al. 2011). 
From the same fish used in the hematological assay, total blood was also collected without anticoagulant to obtain the blood serum used for immunological analyses. Lysozyme activity was measured using spectrophotometry according to Ellis (1990), with lyophilized chicken egg white as standard. For concentration of total plasma protein, a commercial kit (Lab Test ${ }^{\circledR}$ ) was used, with bovine albumin for the standard curve. Total immunoglobulin concentration was assessed according to the method of Amar et al. (2000).

\section{Body centesimal composition and nutrient retention}

For body analyses, 60 fish (20 initial fish, plus 5 per experimental unit, totaling 20 per treatmen) and diet samples were sent to CBO Análises Laboratoriais (Campinas, SP, Brazil) to measure crude protein contents using the Dumas nitrogen combustion method, crude phosphorus. Crude lipids were quantified using the ether extraction method, and ash and moisture were determined using AOAC (2005). These data were used for further analysis and calculation of nitrogen retention, phosphorus retention, and protein efficiency ratio, according to Silva et al. (2016).

\section{Intestinal microbiota assay}

Total DNA extraction, amplification of V3-V4 region of the $16 \mathrm{~S}$ rRNA gene, and Ilumina MiSeq sequencing (300 bp single-end reads) were performed following the protocol established by Neoprospectra Microbiome Technologies, Brazil, and data analyses followed the method described by Schleder et al. (2020), using Usearch (version 10.0.240) in the $\mathrm{R}$ environment. The taxonomic assignment of bacterial sequences was conducted using the SILVA database at 90\% identity (version 132).

\section{Statistical analyses}

All data were first subjected to Bartlett's analysis to verify the homogeneity of variance. Data were assessed by Student's t-test, with 5\% level of significance. Gut microbial data were analyzed with R statistical environment (version 3.5.1).

\section{RESULTS}

Thirteen constituents of $\mathrm{C}$. longa hydrolate were identified, representing approximately $93.50 \%$ of purity, the major compounds being ar-turmerone, $\alpha$-tumerone and $\alpha$-curcumene (Table I).

After 45 days, the treatment supplemented with C. longa hydrolate showed higher survival than the control group, while the other productive indices (final mean weight, productivity, specific growth rate, feed conversion, protein retention) and nutrient retention ( $\mathrm{N}$ and $\mathrm{P}$ ) did not differ between treatments (Table II). Viscerosomatic index, hepatosomatic index and body composition (moisture, crude protein, crude lipid and ash) also did not differ between treatments (Table III).

In the blood profile, fish supplemented with C. longa had a higher count of total leukocytes and neutrophils, as well as mean corpuscular hemoglobin and mean corpuscular hemoglobin concentration, compared to the control group. However, the control showed higher hematocrit, mean corpuscular volume and glucose than these same values in the supplemented group. The other hematological and immunological parameters did not differ between treatments (Table IV).

Raw reads were processed to remove low quality bases, adapters, and trimmed to a fixed length of $280 \mathrm{bp}$ (Trimmomatic, version 0.36). Following quality filtering, $80.5 \%$ of the reads were retained for downstream analysis (average 
Table I. Volatile profile of Curcuma longa hydrolate.

\begin{tabular}{|c|c|c|c|}
\hline Components & RIc & RIl & Percentage (\%) \\
\hline$\alpha$-Phellandrene & 1007 & 1007 & 0.60 \\
\hline p-Cymene & 1026 & 1025 & 3.73 \\
\hline 1.8 -cineol & 1034 & 1033 & 0.54 \\
\hline Terpinolene & 1086 & 1086 & 12.11 \\
\hline$\alpha$-Curcumene & 1484 & 1483 & 6.58 \\
\hline$\alpha$-Zingiberene & 1497 & 1495 & 3.72 \\
\hline$\beta$-Bisabolene & 1511 & 1509 & 11.66 \\
\hline$\beta$-Sesquiphellandrene & 1527 & 1526 & 27.31 \\
\hline ar-tumerone & 1666 & 1669 & 14.21 \\
\hline$\alpha$ Tumerone & 1672 & 1675 & 2.45 \\
\hline Germacrone & 1700 & 1702 & 9.72 \\
\hline Curlone & 1705 & 1705 & 93.50 \\
\hline
\end{tabular}

RIC $=$ Retention index calculated, RII = Retention index of literature, \% = percentage of the component in the volatile fraction of the hydrolate.

of sequences per sample: 81.491). The rarefaction curve and the goods coverage index $(\mathrm{min} / \mathrm{max}$ $=100.0$ ) indicated complete sampling of the bacterial communities in the samples.

The hydrolate group showed a substantial increase in the relative abundance of Cetobacterium and Romboutsia, reflecting higher occurrence of the families Fusobacteraceae and Peptostreptococcaceae and the phyla Fusobacteria and Firmicutes, respectively, in this treatment. Additionally, hydrolate supplementation led to a decrease in the relative abundance of other bacteria, such as Hyphomicrobium and Cryocola, and, consequently, their families (Hyphomicrobiaceae and Microbacteriaceae, respectively) and phyla (Proteobacteria and Actinobacteria, respectively) (Figure 1).

Despite slightly higher richness, the gut microbiota from fish fed diets containing C. longa hydrolate showed lower diversity, most likely from a higher abundance of Cetobacterium and Romboutsia to the detriment to other bacterial groups (Table V).

\section{DISCUSSION}

The chemical composition of essential oils and hydrolates is determined by genetic factors of the plant; however, other factors can cause significant changes in the production of secondary metabolites, such as climate, altitude, nutrition, maturation stage and harvest time (Pettenazzi et al. 2019). In studies carried out by Majolo et al. (2014), ar-tumerone and $\alpha$-tumerone were also observed as major compounds in tumeric oil, albeit in different percentages, $21.0 \%$ and $33.5 \%$, respectively. These differences may have arisen from the use of hydrolate in the present work, whereas Majolo et al. (2014) used the essential oil that commonly has a higher concentration of these compounds.

Analysis of animal growth performance is an important tool during rearing, and it can be used to develop new feeding strategies during the growth of fish, as well as increase yield and profitability. In Table II, average weight, specific growth rate, feed conversion rate, protein and nutrient retention ( $\mathrm{N}$ and $\mathrm{P}$ ) did not differ 
Table II. Growth performance and nutrient retention of Nile tilapia (Oreochromis niloticus) fed a supplemented hydrolate diet from Curcuma longa.

\begin{tabular}{|c|c|c|c|}
\hline Parameters & Hydrolate & Control & Significance (p) \\
\hline Final mean weight (g) & $14.52 \pm 0.76$ & $15.64 \pm 1.76$ & 0.222 \\
\hline Survival (\%) & $95.26 \pm 5.29 *$ & $82.22 \pm 7.20$ & 0.036 \\
\hline Yield (g.m ${ }^{-3}$ ) & $260.91 \pm 33.35$ & $238.76 \pm 7.46$ & 0.195 \\
\hline Specific growth rate (\%.day $\left.{ }^{-1}\right)$ & $2.21 \pm 0.05$ & $2.27 \pm 0.10$ & 0.223 \\
\hline Feed conversation & $1.10 \pm 0.19$ & $1.06 \pm 0.07$ & 0.385 \\
\hline Protein Retention & $0.84 \pm 0.05$ & $0.83 \pm 0.06$ & 0.294 \\
\hline N Retention (\%) & $28.01 \pm 1.54$ & $27.84 \pm 2.39$ & 0.336 \\
\hline P Retention (\%) & $29.24 \pm 3.86$ & $30.52 \pm 2.24$ & 0.362 \\
\hline
\end{tabular}

* Indicates significant differences in the t-test.

between treatments. This work showed that hydrolate supplementation did not present toxicity to fingerlings. In other words, hydrolate did not negatively affect growth performance. These results suggest that the $\mathrm{C}$. longa hydrolate, at a concentration of $2.5 \%$, can be used safely as a food additive. This result corroborates the study of Pereira et al. (2020), showing no differences in weight gain and specific growth rate in Nile tilapia (from 7.45 to $104.03 \mathrm{~g}$ ) fed with a diet supplemented with same hydrolate used in this work, in different doses (0.0, 2.5, 7.5 and 10.0\%).

The higher survival of the group supplemented with hydrolate could be supported by Al-Faragi \& Hassan (2017), that fed juvenile common carp (Cyprinus carpio) with diet supplemented with $C$. longa powder obtained higher survival in reared condition and after infection with Flexibacter columnaris, a bacterium responsible for causing great losses in this life stage.

Fingerlings and new juveniles are very susceptible to several environmental factors that can lead to the proliferation of diseases and, consequently, economic losses. Moreover, fingerlings are sold by unit (Becker 2018), survival becomes one of the most important productive indexes to be evaluated during rearing, because total number or fish is more important than biomass or yield. During these initial phases, several practices can cause the breakdown of the animal's homeostasis, such as capture, biometrics and transport (Urbinati et al. 2014). With this in mind, the use of food additives that promote the survival of tilapia in these phases is extremely important, and the results of this work show the possibility of using C. longa hydrolate for this purpose.

About bromatological composition, the same result was observed in the use of essential oil of oregano as an additive for juvenile Rhamdia quelen, showing that the herbal medicine did not modify metabolism, keeping moisture, lipids, proteins or ash levels equal (Cararo et al. 2017). The same was observed for body indexes, which did not differ between treatments. This result supports a previous study that showed no statistical difference among different doses of C. longa hydrolate, demonstrating that this supplementation has no effect on hepatic metabolism or the accumulation of visceral fat (Pereira et al. 2020).

Hematological parameters are considered essential to assess the general health status of several fish species. Such analysis is considered the quickest way to detect symptoms of physiological stress and identify the presence of disease (Ranzani-Paiva et al. 2013), in addition 
to evaluating the effect of food ingredients and additives.

Among the parameters are glucose, erythrocytes, hematocrit and hemoglobin, which can be affected by several factors, with diet being the most important, followed by fish stress and health status (Barton \& Iwana 1991). These results agree with the study by Ferreira et al. (2017) who observed that supplementation with turmeric powder was effective in reducing stress responses and improving the antioxidant status of lambaris (Astyanax bimaculatus) after transport stress.

During the experiment, no integumentary lesions were observed and no difference in the count of monocytes, immunoglobulins and total plasma protein. More specifically, hydrolate did not cause the breakdown of homeostasis in fish, nor did it result in injury or stress, explaining the absence of changes in these cell counts. This result agrees with another study (Pereira et al. 2020) in which the thrombocyte count did not differ between treatments. Thrombocyte count is related to hemostasis, and these cells are typically present upon injury to an animal's integumentary system (Roberts 2012).

Herbal medicines have had a positive effect on the immune system of animals, modulating and exerting anti-inflammatory and anti-stress activities (Pu et al. 2017, Zhu 2020). As such, these compounds are commonly denoted as immunomodulators, i.e., factors that stimulate and modulate host immunity, presenting a nonspecific response against pathogens and increasing the response of humoral cells (Ferreira et al. 2017). In this work, supplementation with hydrolate stimulated the production of total leukocytes, especially lymphocytes and neutrophils, demonstrating an improvement in the immune system and explaining the higher survival during experimental time.
The dominance of Cetobacterium and Romboutsia in the gut of C. longa hydrolatetreated fish was reflected in lower microbial diversity in these animals. Despite the potential detrimental effect of reducing microbial diversity in the gut, these bacteria are broadly related to the enhancement of gut health and immune response in different vertebrate species (Chen \& Yu 2020, Meng et al. 2019, Wu et al. 2020).

In Nile tilapia, Sakyi et al. (2020) assessed the effect of constant feeding, starvation and refeeding on gut microbiota, metabolism, and antioxidant response. The authors reported the increase of Cetobacterium abundance during feeding and refeeding periods, while Romboutsia increased during the starvation period. They suggested that the production of vitamin B by Cetobacterium is particularly important in fish feeding. Meanwhile, higher levels of Romboutsia during starvation suggested that its capacity to synthesize amino acids and vitamins, as well as utilize simple carbohydrates through different pathways, could have contributed to the physiological improvement observed in Nile tilapias during this period. Therefore, the authors concluded that the abundant variation of these bacteria was positively correlated with the improvement of physiological performance and the reduction of oxidative stress during starvation and re-feeding periods.

Based our results, the dietary addition of $C$. longa hydrolate for Nile tilapia had beneficial effects on the gut microbial community and, most likely, the physiological performance of Nile tilapia by maintaining fish homeostasis. All these effects ensured higher survival in rearing conditions. However, further studies performing a quantitative and more intensive analysis of the gut microbiota of Nile tilapias fed a diet containing $C$. longa hydrolate is needed in order further validate our present findings. 
Table III. Body analyses of Nile tilapia (Oreochromis niloticus) fed a supplemented hydrolate diet from Curcuma longa.

\begin{tabular}{|c|c|c|c|}
\hline \multicolumn{1}{|c|}{ Hydrolate } & Control & Significance (p) \\
\hline \multicolumn{2}{|c|}{ Body indexes } \\
\hline Hepatosomatic & $2.25 \pm 0.27$ & $2.57 \pm 0.25$ & 0.384 \\
\hline Viscerosomatic & $6.36 \pm 0.56$ & $6.32 \pm 0.26$ & 0.473 \\
\hline \multicolumn{2}{|c|}{ Body composition } \\
\hline Moisture (\%) & $68.33 \pm 0.94$ & $67.29 \pm 1.41$ & 0.396 \\
\hline Crude Protein & $16.82 \pm 1.84$ & $16.06 \pm 2.32$ & 0.365 \\
\hline Crude Lipid & $11.03 \pm 1.49$ & $12.64 \pm 2.32$ & 0.299 \\
\hline Ash & $2.62 \pm 0.12$ & $2.63 \pm 0.09$ & 0.356 \\
\hline
\end{tabular}

Table IV. Blood profile of Nile tilapia (Oreochromis niloticus) fed a supplemented hydrolate diet from Curcuma longa.

\begin{tabular}{|c|c|c|c|}
\hline Parameters & Hydrolate & Control & Significance (p) \\
\hline \multicolumn{4}{|c|}{ Total and differential count } \\
\hline Thrombocytes $\left(\times 10^{3} \cdot \mu \mathrm{L}^{-1}\right)$ & $12.81 \pm 4.12$ & $6.96 \pm 3.15$ & 0.127 \\
\hline Leukocytes $\left(\times 10^{3} . \mu \mathrm{L}^{-1}\right)$ & $21.34 \pm 0.34^{*}$ & $14.64 \pm 0.07$ & 0.046 \\
\hline Lymphocytes $\left(\times 10^{3} \cdot \mu \mathrm{L}^{-1}\right)$ & $19.64 \pm 5.18^{*}$ & $13.7 \pm 0.50$ & 0.411 \\
\hline Monocytes $\left(\times 10^{3} \cdot \mu \mathrm{L}^{-1}\right)$ & $0.58 \pm 0.29$ & $0.47 \pm 0.16$ & 0.286 \\
\hline Neutrophils $\left(\times 10^{3} \cdot \mu \mathrm{L}^{-1}\right)$ & $1.12 \pm 0.24^{*}$ & $0.46 \pm 0.19$ & 0.031 \\
\hline \multicolumn{4}{|c|}{ Hematimetric } \\
\hline Erythrocytes $\left(10^{6} \mu \mathrm{L}^{-1}\right)$ & $1.31 \pm 0.04$ & $1.22 \pm 0.14$ & 0.248 \\
\hline Hematocrit (\%) & $24.90 \pm 0.49$ & $27.47 \pm 0.41^{\star}$ & 0.001 \\
\hline Hemoglobin $\left(\mathrm{g} / \mathrm{dL}^{-1}\right)$ & $7.21 \pm 0.79$ & $12.37 \pm 2.00^{*}$ & 0.014 \\
\hline Mean corpuscular volume $\left(10^{4} . \mathrm{fL}\right)$ & $1.95 \pm 0.04$ & $2.43 \pm 0.24^{\star}$ & 0.023 \\
\hline Mean corpuscular hemoglobin $\left(10^{4} . \mathrm{pg}\right)$ & $5.74 \pm 0.09^{*}$ & $1.00 \pm 0.20$ & 0.031 \\
\hline Mean corpuscular hemoglobin concentration (g.dL-1) & $36.78 \pm 5.71^{\star}$ & $24.16 \pm 3.22$ & 0.024 \\
\hline \multicolumn{4}{|c|}{ Immunological } \\
\hline Glucose $\left(m g . d L^{-1}\right)$ & $49.50 \pm 2.35$ & $54.33 \pm 9.79 *$ & 0.026 \\
\hline Total Plasma Protein (mg. L $\left.^{-1}\right)$ & $1047.87 \pm 10.38$ & $1050.73 \pm 9.05$ & 0.312 \\
\hline Total Plasma Immunoglobulin (mg. L $^{-1}$ ) & $32.63 \pm 2.15$ & $34.72 \pm 4.52$ & 0.287 \\
\hline
\end{tabular}

* Indicates significant differences in the t-test. 

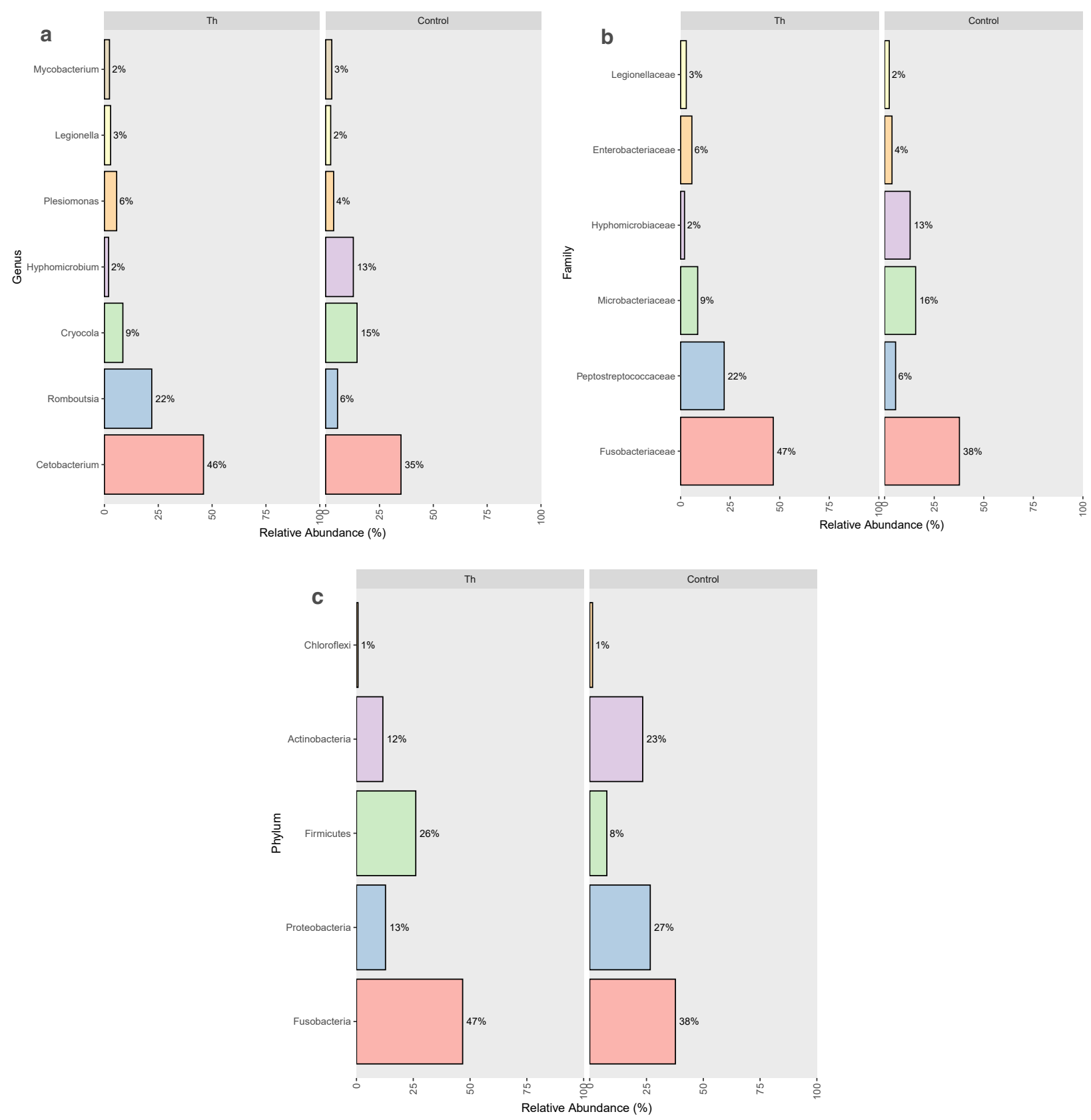

Figure 1. Bacterial relative abundance Nile tilapia (Oreochromis niloticus) fed a supplemented hydrolate diet from Curcuma longa. (Control). a, Genus; b, Families; c, Phyla.

Table V. Richness, Chao1 and the diversity indexes, Shannon and Inverse Simpson, of gut microbiota from Nile tilapia (Oreochromis niloticus) fed a diet supplemented with Curcuma longa hydrolate.

\begin{tabular}{|c|c|c|c|c|c|c|}
\hline Treatments & No.seqs & Goods & Richness & Chao1 & Inverse_simpson & Shannon \\
\hline Control & 72838 & 100.0 & 66.0 & 66.0 & 63.3 & 26.9 \\
\hline Hydrolate & 72838 & 100.0 & 82.0 & 79.3 & 36.7 & 19.6 \\
\hline
\end{tabular}




\section{REFERENCES}

ABDEL-TAWWAB M \& ABBASS FE. 2017. Turmeric powder, Curcuma longa L., in common carp, Cyprinus carpio L., diets: growth performance, innate immunity, and challenge against pathogenic Aeromonas hydrophila infection. Journal of the World Aquaculture Society 48.2: 303-312.

AL-FARAGI JK \& HASSAN MAH. 2017. Efficiency of dietary turmeric on growth performance, hematology and survival rate in common carp Cyprinus carpio challenged with Flexibacter columnaris. Kufa J Vet Med Sci 8.1: 130-140.

AMAR EC, KIRON V, SATOH S, OKAMOTO N \& WATANABE T. 2000. Effects of dietary $\beta$ carotene on the immune response of rainbow trout Oncorhynchus mykiss. Fish Sci 66(6): 1068-1075.

ANDRADE JIA, JERÔNIMO GT, NUNEZ CV, DOS SANTOS RB, ARAÚJO JKO, RUIZ ML \& MARTINS ML. 2018. Hematology and biochemistry of Colossoma macropomum coinfected with Aeromonas hydrophila and monogenean Anacanthorus spathulatus after treatment with seed extract of Bixa orellana. Aquaculture 495: 452-457.

ANUÁRIO PEIXE-BR DA PISCICULTURA. 2021. ASSOCIAÇÃO BRASILEIRA DE PISCICULTURA. 2021. São Paulo: PeixeBR,

AOAC - ASSOCIATION OF OFFICIAL ANALYTICAL CHEMISTS. 2005. Official Methods of the AOAC International, 18th ed., Maryland, USA.

APHA-AMERICAN PUBLIC HEALTH ASSOCIATION. 2005. American Water Works Association, Water Pollution Control Association. Standard Methods for the Examination of Water and Wastewater, 21st ed., American Public Health Asso-ciation, Washington, DC, USA.

BARTON BA \& IWAMA GK. 1991. Physiological changes in fish from stress in aquaculture with emphasis on the response and effects of corticosteroids. Annu Rev Fish Dis 1: 3-26.

BECKER M. 2018. Avaliação in vitro e in vivo do potencial antibacteriano de extratos de plantas no cultivo intensivo de alevinos de tilápia Oreochromis niloticus na fase de juvenil, $108 \mathrm{p}$.

BERGLEITER S \& SIMON M. 2015. Certification standards for aquaculture products: bringing together the values of producers and consumers in globalised organic food markets. J Agric Environ Ethics 28.3: 553-569.

CABELLO FC, GODFREY HP, TOMOVA A, IVANOVA L, DÖLZ H, MILLANAO A \& BUSCHMANN AH. 2013. Antimicrobial use in aquaculture re-examined: its relevance to antimicrobial resistance and to animal and human health. Environ Microbiol 15(7): 1917-1942.

CARARO LM, SADO RY, MUELBERT B \& DE BORBA MR. 2017. Evaluation of oregano essential oil as a growth promoter and resistance stimulator against Ichthyophthirius multifiliis (Protozoa, Ciliophora) in silver catfish juveniles, Rhamdia sp. (Siluriformes, Heptapteridae). Semina: Ciências Agrárias 38(6): 3871-3885.

CATÃO HCRM, AQUINO CF, SALES NLP, ROCHA FS, CAIXETA F \& CIVIL N. 2018. Hidrolatos e extratos vegetais sobre a qualidade de sementes de mamona armazenadas em condições não controladas. Rev Bras Ciênc Agrár (Agrária) 13(2): 5539.

CHEN J \& YU Y. 2021. Bacillus subtilis-fermented products ameliorate the growth performance and alter cecal microbiota community in broilers under lipopolysaccharide challenge. Poult Sci 100(2): 875-886.

CORADI PC, MÜLLER A, SCHMIDT DA, LIMA RE, BAIO FR, BORSATO AV \& BLANCO M. 2018. Electric conductivity test for quality assessment of aromatic and medicinal plants after drying. Dry Technol 36(5): 545-556.

DE SOUZA COSTA CM, DA CRUZ MG, LIMA TBC, FERREIRA LC, VENTURA AS, BRANDÃO FR \& JERÔNIMO GT. 2020. Efficacy of the essential oils of Mentha piperita, Lippia alba and Zingiber officinale to control the acanthocephalan Neoechinorhynchus buttnerae in Colossoma macropomum. Aquac Rep 18: 100414.

DOOL HVD \& KRATZ PD. 1963. A generalization of the retention index system including linear temperature programmed gas-liquid partition chromatography. J Chromatogr A 11: 463-471. Available from <https:// worldveg.tind.io/record/1766/> Accessed: Jul. 2020.

ELLIS AE. 1990. Lysozyme assays. Techniques in fish immunology 1: 101-103.

FERREIRA PDMF, MARTINS MTS, CALDAS DW, GOMES JR, DE OLIVEIRA JM \& ZUANON S. 2017. Curcuma longa as additive in the diet for Astyanax aff. bimaculatus. Fish Physiol Biochem 43(3): 691-702.

JATOBÁ A, DA SILVA BC, DA SILVA JS, DO NASCIMENTO VIEIRA F, MOURIÑO JLP, SEIFFERT WQ \& TOLEDO TM. 2014. Protein levels for Litopenaeus vannamei in semi-intensive and biofloc systems. Aquaculture 432: 365-371.

JATOBÁ A, DO NASCIMENTO VIEIRA F, BUGLIONE-NETO CC, MOURIÑO JLP, SILVA BC, SEIFTTER WQ \& ANDREATTA ER. 2011. Diet supplemented with probiotic for Nile tilapia in polyculture system with marine shrimp. Fish Physiol Biochem 37(4): 725-732. 
JATOBÁ A, KLIPP SP \& HOPPE R. 2016. Primeiro relato de Francisella noatunensis subespécie orientalis no sul do Brasil-relato de caso. Acta Vet Bras 10(2): 172-176.

KOCAADAM B \& ŞANLIER NE. 2017. Curcumin, an active component of turmeric (Curcuma longa), and its effects on health. Crite Rev food Sci Nutr 57(13): 2889-2895.

LUNKES CL, PAIVA IM, RUBIM FM, DE OLIVEIRA RIBEIRO A \& MURGAS LSD. 2018. Consumo de carnes e percepção dos universitários de Lavras-MG em relação a carne de peixe e seus benefícios à saúde. Arch Latinoam Nutr 68(4): 295-302.

MAJOLO C, NASCIMENTO VP, CHAGAS EC \& CHAVES FCM. 2014. Atividade antimicrobiana do óleo essencial de rizomas de açafrão (Curcuma longa L.) e gengibre (Zingiber officinale Roscoe) frente a salmonelas entéricas isoladas de frango resfriado. Rev Bras Pl Med 16(3): 505-512.

MELLO V, VILELA F, DAEMON E, PRATA M \& AMARAL M. 2015. EFICÁCIA CARRAPATICIDA DE FORMULAÇÕES CONTENDO ÓLEO ESSENCIAL E HIDROLATO DE ROsmarinus officinalis. Rev Biotecnol Ciênc (ISSN 2238-6629) 4(1).

MENG X, HU W, WU S, ZHU Z, LU R, YANG G, QIN C, YANG L \& NIE G. 2019. Chinese yam peel enhances the immunity of the common carp (Cyprinus carpio L.) by improving the gut defence barrier and modulating the intestinal microflora. Fish Shellfish Immunol 95: 528-537.

PEREIRA MO, MORAES AV, RODHERMEL JCB, HESS JD, ALVES L, CHAABAN A \& JATOBÁ A. 2020. Supplementation of Curcuma longa hydrolate improves immunomodulatory response in Nile tilapia reared in a recirculation aquaculture system. Arq Bras Med Vet Zootec 72(5): 1805-1812.

PETTENAZZI GB, BERNUCI KZ \& SANTOS RM. 2019. A composição química e atividade antimicrobiana e antioxidante de óleos essenciais de plantas brasileiras. Disponivel em: http://rdu.unicesumar.edu.br/handle/123456789/3918.

PU H, LI X, DU Q, CUI H \& XU Y. 2017. Research progress in the application of Chinese herbal medicines in aquaculture: a review. Engineering 3(5): 731-737.

RANZANI-PAIVA MJT, PÁDUA SB, TAVARES-DIAS M \& EGAMI MI. 2013. Métodos para análise hematológica em peixes. Paraná: Universidade Estadual de Maringá-EDUEM.

ROBERTS RJ. 2012. Fish pathology. J Wiley \& Sons.

SAKYI ME, CAI J, TANG J, XIA L, LI P, ABARIKE ED \& JIAN J. 2020. Short term starvation and re-feeding in Nile tilapia (Oreochromis niloticus, Linnaeus 1758): Growth measurements, and immune responses. Aquac Rep 16: 100261.
SALINAS I \& PARRA D. 2015. Fish mucosal immunity: intestine. In Mucosal health in aquaculture (p. 135-170). Academic Press.

SILVA BC, VIEIRA FN, MOURIÑO JLP, BOLIVAR N \& SEIFFERT WQ. 2016. Butyrate and propionate improve the growth performance of Litopenaeus vannamei. Aquac Res 47(2): 612-623.

SINGH N, GUPTA S \& RATHORE V. 2017. Comparative antimicrobial study of ethanolic extract of leaf and rhizome of Curcuma longa Linn. Pharmacogn J 9(2).

TORRES MC. 2019. Resistência antimicrobiana em populações animais e seu impacto na saúde pública: uma revisão da literatura.

URBINATI EC, ZANUZZO FS \& BILLER-TAKAHASHI JD. 2014. Estresse e sistema imune em peixes. Biologia e fisiologia de peixes neotropicais de água doce, p. 87-105.

VENSKUTONIS PR, DAPKEVICIUS A \& BARANAUSKIENE $M$. 1997. Composition of the essential oil of Lavender (Lavandula angustifolia Mill.) from Lithuania. J Essent Oil Res 9(1): 107-110. Available from <https://doi.org/10.1 080/10412905.1997.9700727> Accessed: Nov. 24, 2019. doi: 10.1080/10412905.1997.9700727.

VICENTE IS, ELIAS F \& FOSNECA-ALVES CE. 2014. Perspectivas da produção de tilápia do Nilo (Oreochromis niloticus) no Brasil. Rev Ciênc Agrár 37(4): 392-398.

WU X, CAO J, LI M, YAO P, LI H, ZU W, YUAN C, LI J, WANG S, LI $P$ \& WANG Y. 2020. An integrated microbiome and metabolomic analysis identifies immunoenhancing features of Ganoderma lucidum spores oil in mice. Pharmacol Res 158: 104937.

YUSUF M, HASSAN MA, TAG HM, SARIVISTAVA K, REDDY PG \& HASSAN AM. 2017. Influence of turmeric (Curcuma longa) on performance, histomorphology and microbiota of intestine in juvenile tilapia (Oreochromis niloticus). Int J Agric Sci Vet Med 5: 7-16.

ZHU F. 2020. A review on the application of herbal medicines in the disease control of aquatic animals. Aquaculture 526: 735422.

\footnotetext{
How to cite

PEREIRA MO, HESS JD, RODHERMEL JCB, FARIAS DR, SCHLEDER DD, ALVES L, BERTOLDI FC, CHABAN A, DE ANDRADE JIA \& JATOBÁ A. 2021. Curcuma longa hydrolate improves Nile tilapia survival in a recirculation rearing system, maintaining the animal homeostasis and modulating the gut microbial community. An Acad Bras Cienc 93: e20210088. DOI 10.1590/0001-3765202120210088.
} 
Manuscript received on January 21, 2021;

accepted for publication on July 21, 2021

\section{MARINA O. PEREIRA}

https://orcid.org/0000-0003-1339-9543

JULIA D. HESS ${ }^{2}$

https://orcid.org/0000-0002-6089-3352

\section{JULIO CESAR B. RODHERMEL ${ }^{2}$}

https://orcid.org/0000-0002-1493-5101

\section{DANIEL R. FARIAS ${ }^{3}$}

https://orcid.org/0000-0003-4531-0195

DELANO D. SCHLEDER ${ }^{4}$

https://orcid.org/0000-0002-1318-8298

\section{LUCIANO ALVES ${ }^{5}$}

https://orcid.org/0000-0003-0565-5738

FABIANO C. BERTOLDI ${ }^{6}$

https://orcid.org/0000-0003-4750-5164

\section{AMANDA CHABAN ${ }^{7}$}

https://orcid.org/0000-0002-8066-5242

\section{JAQUELINE I.A. DE ANDRADE ${ }^{2}$}

https://orcid.org/0000-0002-9907-9948

\section{ADOLFO JATOBÁ ${ }^{4}$}

https://orcid.org/0000-0002-9470-4775

${ }^{1}$ GeneSeas Aquacultura, Rodovia Selviria/Aparecida do Taboado, Zona Rural, 79590-000 Selviria, MS, Brazil ${ }^{2}$ Instituto Federal Catarinense, Câmpus Araquari, Laboratório de Aquicultura, BR-280, Km 27, Caixa Postal 27, 89245-000 Araquari, SC, Brazil

${ }^{3}$ Programa de Pós-Graduação em Tecnologia e Ambiente, Instituto Federal Catarinense, Laboratório de Produção Vegetal, Câmpus Araquari, BR-280, Km 27, Caixa Postal 27, 89245-000 Araquari, SC, Brazil
${ }^{4}$ Programa de Pós-Graduação em Tecnologia Ambiental, Instituto Federal Catarinense, Laboratório de Aquicultura, Câmpus Araquari, BR-280, Km 27,

Caixa Postal 27, 89245-000 Araquari, SC, Brazil

${ }^{5}$ Instituto Federal Catarinense, Laboratório de Microbiologia, Fitossanidade e Propagação Vegetal, Câmpus Araquari, BR280, Km 27, Caixa Postal 21, 89245-000 Araquari, SC, Brazil

${ }^{6}$ Empresa de Pesquisa Agropecuária e Extensão Rural de Santa Catarina/EPAGRI, Laboratório de Óleos Essenciais, Av. Antônio Heil, 6800, Iaipava, 88316-002 Itajaí, SC, Brazil 'Instituto Federal Catarinense, Câmpus Araquari, BR-280, Km 27, Caixa Postal 27, 89245-000 Araquari, SC, Brazil

Correspondence to: Adolfo Jatobá

E-mail: jatobaadolfo@gmail.com

\section{Author contributions}

MOP and AJ participated collectively in all steps of the letter writting, editing, review and submission, which includes literature review, data collection, the presentation of its main results and discussion. MOP, JDH and JCBR were responsible for fish handling and data collection. DRF and DDS carried out intestinal microbiota assay. LA and FCB prepared the hydrolate for use. AC and JIAA carried out hematological and immunological analysis.

\section{(c) BY}

